\title{
Evaluation of Cement Kiln Dust (CKD) as an Amendment for the Sandy Soils . 1- Preliminary Studies
}

\author{
M. A. Morsy, G. M. El-Dawwy, H. A. Hassan and K. H. \\ Mohammed \\ Soil Science Department, Faculty of Agriculture, El-Minia, \\ University, El-Minia, Egypt.
}

\begin{abstract}
7 THE REUSE of some industrial wastes or by-products such as the cement kiln dust (CKD) is beneficial to prevent or at least to reduce the environmental pollution. The CKD is beneficial as a raw material, construction material, absorbent, and improving the sandy soil properties. Preliminary studies were carried out to study the possibility of using the CKD as an amendment for the sandy soils. Two cement kiln dusts were investigated, one was collected from El-Minia white cement factory and the other was collected from Beni - Suef black cement factory. The two CKD had a high total soluble salts (T.S.S.), soluble cations $\left(\mathrm{Ca}^{+2}, \mathrm{Mg}^{+2}, \mathrm{Na}^{+}\right.$and $\left.\mathrm{K}^{+}\right)$and soluble anions $\left(\mathrm{CO}_{3}^{-2}, \mathrm{HCO}_{3}^{-}, \mathrm{Cl}^{-}\right.$and $\left.\mathrm{SO}_{4}^{-2}\right)$ therefore, each $\mathrm{CKD}$ was modified by leaching with water using four leaching treatments (leaching with $0,5,10$ and 20 times water). Thereafter, a pot experiment using a sandy soil cultivated with corn was set up to study the efficiency of using the modified white CKD (leached with 20 times water) as a soil amendment. The modified white CKD was applied to the sandy soil at six rates $\left(0,5,10,15,20\right.$ and $\left.25 \mathrm{Mg} \mathrm{ha}^{-1}\right)$. The obtained results of the current study show that the T.S.S., $\mathrm{Cl}^{-}, \mathrm{Na}^{+}$and $\mathrm{K}^{+}$of the raw black CKD were higher than those of the raw white CKD, however, the $\mathrm{CO}_{3}{ }^{-2}, \mathrm{Ca}^{+2}$ and $\mathrm{Mg}^{+2}$ of the raw white CKD were higher than those of the raw black CKD. Leaching the two CKD with water decreased the T.S.S. and soluble ions. The best leaching treatment for modifying the CKD is the leaching with 20 times water. The leaching efficiency for the white CKD was better than that for the black one. Application of the modified white CKD at the rate of $25 \mathrm{Mg} \mathrm{ha}^{-1}$ to the sandy soil decreased the real density, porosity, percolation rate, and infiltration rate; while; it increased the plant height, fresh and dry weight of the corn shoots, and water use efficiency by the plants, but it decreased the water consumptive use by the plants. In general, application of the modified white CKD improves the sandy soil properties, decreases the lost water by leaching, rationalizes the irrigation water use, and enhances the corn growth. It could be recommended to use the modified white $\mathrm{CKD}$ at the rate of $25 \mathrm{Mg} \mathrm{ha}^{-1}$ as an amendment for the sandy soils under the conditions of EI-Minia Governorate.
\end{abstract}

Keywords: Sandy soil, Cement kiln dust, Amendment and corn.

Cement kiln dust (CKD) is a significant by-product material of the cement manufacturing process (Adaska and Taubert, 2008). The cement kiln dust vary markedly from plant to plant in chemical, mineralogical and physical 
composition, depending upon the feed raw materials, type of kiln operation, dust collection facility and the fuel used (Klemm, 1980). The particle size of CKD is dependent upon the type of kiln operation (Adaska and Taubert, 2008).

The globally growing demand of cement results in towering collection of kiln dust from cement plants. The disposal of this fine dust is very difficult and poses an environmental threat (Rahman et al., 2011). The cement industry in Egypt applies dry processes in cement manufacture and releases a large amount of CKD, which is considered as a waste and a pollutant. Therefore, it was desired to make use of this waste and to save the environment (Waly et al., 2007). A medium size cement plant may produce up to 30000 tons of CKD annually (Rahman et al., 2011).

In order to minimize the undesirable environmental impacts and to conserve materials, many researches have been conducted to investigate the beneficial commercial uses of CKD as a raw material, construction material, base stabilizing for pavements, low-strength backfill, municipal landfill cover, adsorbent, waste water treatment, waste remediation, fertilizer, agricultural soil enhancement and improving sandy soil properties (El-Awady and Sami, 1997, Adaska and Taubert, 2008, Rodd et al., 2009 and Rahman et al., 2011).

Application of the cement kiln dust improves the sandy soil properties so as to provide suitable conditions for the plant growth. Rahman et al. (2011) observed that as the CKD increases from $0 \%$ to $50 \%$ by weight of soil, the maximum dry density of the sandy sabkha soil (indigenous Saudi Arabia soil) was decreased from 1.920 to $1.716 \mathrm{~g} / \mathrm{cm}^{3}$. Similarly, the moisture content was increased from $9.58 \%$ (for $0 \%$ CKD) to $14.52 \%$ (for $50 \%$ CKD). Schreiber et al. (1998) pointed out that due to its ability to hold water from $40 \%$ to $50 \%$ of its weight, CKD can assist in drought resistance. Rahman et al. (2011) reported that the permeability of silty fine sand was somewhat decreased from $3 \times 10^{-3}$ to $1 \times 10^{-4} \mathrm{~cm} / \mathrm{sec}$ when treated with $20 \% \mathrm{CKD}$.

The agriculture use of the cement kiln dust is a useful management practice as it is a soil conditioner and a source of nutrients to increase the crop yield. Carroll et al. (1964) studied several different types of the cement dusts as a replacement of chemical fertilizer. They found that the cement dusts have the same ability to increase yields of alfalfa. The dust could supply plants with enough amounts of $\mathrm{S}, \mathrm{Mg}$ and $\mathrm{K}$. Khader and Abu-Rub (1986) studied the possibility of using CKD as a fertilizer, however, CKD did not show any significant effect on the dry matter yield of barley when planted in sand and soil mixed with CKD. Therefore, one should remember that these beneficial usages critically depend on the chemical and physical properties of the CKD. Naylor and Dangeau (1985) suggested the agriculture use of CKD as a beneficial management practice. The U.S. Bureau of Mines reported that CKD contained beneficial amounts of crop micro- and macro-nutrients (Hynes and Kramer, 1982). In Australia, Dan et al. (1989) found that CKD increased the crop yield equally well as crushed limestone. Fraiman et al. (1991) recommended the use of bypass dust containing high levels of $\mathrm{K}_{2} \mathrm{O}, \mathrm{SO}_{3}$ and $\mathrm{Cl}$, in fertilizer applications. Rahman et al. (2011) concluded that CKD may be useful as a soil conditioner and source of nutrient to enhance crop yield.

Egypt. J. Soil Sci. 53, No. 3 (2013) 
The main objectives of the current study are to evaluate the cement kiln dust of El-Minia and Beni - Suef cement factories as a soil amendment and to study its effect on some soil properties, growth and water use efficiency by corn plants grown in a sandy soil.

Soil

\section{Material and Methods}

The used soil in this study was loamy sand and collected from the newly reclaimed desert land at western district of the Nile Valley, West of Samalout, El-Minia Governorate. Some analytical data of the studied soil are given in Table 1.

\section{TABLE 1. Some analytical data of the studied soil.}

\begin{tabular}{|l|c|}
\hline \multicolumn{1}{|c|}{ Soil properties } & Value \\
\hline Particle size distribution: & \\
Coarse sand (\%) & 52.1 \\
Fine sand (\%) & 30.1 \\
Silt $(\%)$ & 15.8 \\
Clay $(\%)$ & 2.0 \\
Texture grade & Loamy sand \\
\hline $\mathrm{pH}(1: 2.5)$ & 7.9 \\
\hline $\mathrm{CaCO}\left(\mathrm{g} \mathrm{kg}^{-1}\right)$ & 105.0 \\
\hline $\mathrm{OM}\left(\mathrm{g} \mathrm{kg}^{-1}\right)$ & 6.6 \\
\hline $\mathrm{EC}(1: 5)\left(\mathrm{dS} \mathrm{m}{ }^{-1}\right)$ & 0.7 \\
\hline Soluble cations $\left(\boldsymbol{g ~ k g}^{-1}\right):$ & \\
$\mathrm{Ca}^{+2}$ & 0.4 \\
$\mathrm{Mg}^{+2}$ & 0.1 \\
$\mathrm{Na}^{+}$ & 0.1 \\
$\mathrm{~K}^{+}$ & 0.01 \\
\hline${\text { Soluble anions }\left(\mathbf{g ~ k g}^{-1}\right):}_{\mathrm{Cl}^{-}}$ & \\
$\mathrm{SO}_{4}^{-2}$ & 0.1 \\
$\mathrm{CO}_{3}^{-2}$ & 1.8 \\
$\mathrm{HCO}_{3}^{-}$ & ---- \\
\hline
\end{tabular}

\section{Cement kiln dust (CKD)}

Two cement kiln dusts were tested, one was collected from El-Minia white cement factory and the other was collected from Beni - Suif black cement factory. Some analytical data of the tested CKD are given in Table 2.

\section{Cement kiln dust modification}

Each CKD was modified by leaching with water using four leaching treatments (leaching with 0, 5, 10 and 20 times water). After leaching and drying, the CKD samples were analyzed for E.C., soluble cations and anions as shown in Table 3. 
TABLE 2. Comparison between the raw black CKD and white CKD.

\begin{tabular}{|l|c|c|}
\hline \multicolumn{1}{|c|}{$\begin{array}{c}\text { CKD } \\
\text { Chemical properties }\end{array}$} & $\begin{array}{c}\text { Raw black } \\
\text { CKD }\end{array}$ & $\begin{array}{c}\text { Raw white } \\
\text { CKD }\end{array}$ \\
\hline $\mathrm{EC}\left(\mathrm{dS} \mathrm{m}^{-1}\right)$ & 21.6 & 10.3 \\
\hline $\mathrm{Ca}^{+2}\left(\mathrm{~g} \mathrm{~kg}^{-1}\right)$ & 4.0 & 9.2 \\
\hline $\mathrm{Mg}^{+2}\left(\mathrm{~g} \mathrm{~kg}^{-1}\right)$ & 0.1 & 0.2 \\
\hline $\mathrm{Na}^{+}\left(\mathrm{g} \mathrm{kg}^{-1}\right)$ & 1.4 & 0.3 \\
\hline $\mathrm{K}^{+}\left(\mathrm{g} \mathrm{kg}^{-1}\right)$ & 5.2 & 0.2 \\
\hline $\mathrm{Cl}^{-}\left(\mathrm{g} \mathrm{kg}^{-1}\right)$ & 45.0 & 2.8 \\
\hline $\mathrm{SO}_{4}^{-2}\left(\mathrm{~g} \mathrm{~kg}^{-1}\right)$ & 0.4 & 4.8 \\
\hline $\mathrm{CO}_{3}^{-2}\left(\mathrm{~g} \mathrm{~kg}^{-1}\right)$ & 5.9 & 7.0 \\
\hline $\mathrm{HCO}_{3}^{-}\left(\mathrm{g} \mathrm{kg}^{-1}\right)$ & --- & ----- \\
\hline
\end{tabular}

TABLE 3. Effect of leaching on some chemical properties of the two tested CKDs.

\begin{tabular}{|c|c|c|c|c|c|c|c|c|}
\hline \multirow{2}{*}{$\begin{array}{c}\text { CKD } \\
\text { chemical } \\
\text { properties }\end{array}$} & \multicolumn{4}{|c|}{$\begin{array}{l}\text { Leaching treatments for the } \\
\text { black CKD }\end{array}$} & \multicolumn{4}{|c|}{$\begin{array}{l}\text { Leaching treatments for the } \\
\text { white CKD }\end{array}$} \\
\hline & $\begin{array}{c}\text { 0 } \\
\text { Times } \\
\text { water }\end{array}$ & \begin{tabular}{c}
\multicolumn{1}{c}{5} \\
Times \\
Water*
\end{tabular} & $\begin{array}{c}10 \\
\text { Times } \\
\text { water }\end{array}$ & $\begin{array}{c}20 \\
\text { Times } \\
\text { water }\end{array}$ & $\begin{array}{c}\text { 0 } \\
\text { Times } \\
\text { water }\end{array}$ & $\begin{array}{c}5 \\
\text { Times } \\
\text { water }\end{array}$ & $\begin{array}{c}10 \\
\text { Times } \\
\text { water }\end{array}$ & $\begin{array}{c}20 \\
\text { Times } \\
\text { water }\end{array}$ \\
\hline $\mathrm{EC}\left(\mathrm{dS} \mathrm{m} \mathrm{m}^{-1}\right)$ & 21.6 & 14.7 & 12.6 & 10.8 & 10.3 & 7.4 & 6.1 & 4.8 \\
\hline $\mathrm{Ca}^{+2}\left(\mathrm{~g} \mathrm{~kg}^{-1}\right)$ & 4.0 & 2.6 & 2.0 & 1.3 & 9.2 & 5.2 & 4.5 & 4.1 \\
\hline $\mathrm{Mg}^{+2}\left(\mathrm{~g} \mathrm{~kg}^{-1}\right)$ & 0.1 & 0.1 & 0.1 & 0.1 & 0.2 & 0.1 & 0.1 & 0.1 \\
\hline $\mathrm{Na}^{+}\left(\mathrm{g} \mathrm{kg}^{-1}\right)$ & 1.4 & 0.6 & 0.5 & 0.4 & 0.3 & 0.2 & 0.1 & 0.1 \\
\hline $\mathrm{K}^{+}\left(\mathrm{g} \mathrm{kg}^{-1}\right)$ & 5.2 & 4.8 & 2.8 & 1.5 & 0.2 & 0.1 & 0.1 & 0.1 \\
\hline $\mathrm{Cl}^{-}\left(\mathrm{g} \mathrm{kg}^{-1}\right)$ & 45.0 & 15.0 & 13.0 & 7.5 & 2.8 & 0.9 & 0.4 & 0.2 \\
\hline $\mathrm{SO}_{4}^{-2}\left(\mathrm{~g} \mathrm{~kg}^{-1}\right)$ & 0.4 & 0.3 & 0.3 & 0.2 & 4.8 & 3.8 & 2.6 & 2.2 \\
\hline $\mathrm{CO}_{3}^{-2}\left(\mathrm{~g} \mathrm{~kg}^{-1}\right)$ & 5.9 & 5.6 & 5.3 & 5.1 & 7.0 & 5.0 & 4.8 & 2.8 \\
\hline $\mathrm{HCO}_{3}^{-}\left(\mathrm{g} \mathrm{kg}^{-1}\right)$ & ---- & ---- & ---- & ---- & ---- & --- & ---- & ---- \\
\hline
\end{tabular}

* 5 Times water $=$ The CKD was leached with 5 times water.

Egypt. J. Soil Sci. 53, No. 3 (2013) 
Effect of the modified white CKD on some physical properties of sandy soils

The modified white CKD (leached with 20 times water) was applied to the sandy soil at six rates $\left(0,5,10,15,20\right.$ and $\left.25 \mathrm{Mg} \mathrm{ha}^{-1}\right)$. The modified white CKD. The particle and bulk densities, porosity, percolation rate, and infiltration rate were determined and presented in Table 4.

TABLE 4. Effect of the modified white CKD on some physical properties of the sandy soil.

\begin{tabular}{|c|c|c|c|c|c|}
\hline $\begin{array}{c}\text { CKD } \\
\text { treatments } \\
\left(\mathbf{M g ~ h a}^{-\mathbf{1}}\right)\end{array}$ & $\begin{array}{c}\text { Bulk } \\
\text { density } \\
\left(\mathbf{M g ~ m}^{-\mathbf{3}}\right)\end{array}$ & $\begin{array}{c}\text { Particle } \\
\text { density } \\
\left(\mathbf{M g ~ m}^{-3}\right)\end{array}$ & $\begin{array}{c}\text { Total } \\
\text { porosity } \\
(\mathbf{\%})\end{array}$ & $\begin{array}{c}\text { Percolation } \\
\text { rate } \\
\left(\mathbf{c m ~ m i n}^{\mathbf{- 1}}\right)\end{array}$ & $\begin{array}{c}\text { Infiltration } \\
\text { rate } \\
\left(\mathbf{c m ~ m i n}^{-\mathbf{1}}\right)\end{array}$ \\
\hline Control $(0.0)$ & 1.57 & 2.77 & 43.32 & 1.75 & 0.78 \\
\hline 5 & 1.55 & 2.73 & 43.22 & 1.56 & 0.71 \\
\hline 10 & 1.54 & 2.71 & 43.17 & 1.40 & 0.64 \\
\hline 15 & 1.54 & 2.67 & 42.32 & 1.27 & 0.60 \\
\hline 20 & 1.52 & 2.57 & 40.86 & 1.22 & 0.58 \\
\hline 25 & 1.52 & 2.55 & 40.39 & 1.17 & 0.57 \\
\hline
\end{tabular}

Pot experiment: Effect of the modified white CKD on some corm vegetative growth parameters and water use by the corn plants

The modified white CKD was applied to the sandy soil at six rates $(0,5,10$, 15, 20 and $25 \mathrm{Mg} \mathrm{ha}^{-1}$ ). Each treatment was replicated 3 times. Five $\mathrm{kg}$ of the air dried treated soil were filled in a plastic pot $(16 \mathrm{~cm}$ diameter and $20 \mathrm{~cm}$ depth). Five grains of corn (Zea mayz) were planted in each pot on 27 July 2011. Two plants were finally left to grow in each pot and received the normal fertilization of organic manure, $\mathrm{N}, \mathrm{P}$ and $\mathrm{K}$ at the equivalent rates of $25 \mathrm{Mg}$ organic manure, $247.5 \mathrm{~kg} \mathrm{~N}, 155 \mathrm{~kg} \mathrm{P}_{2} \mathrm{O}_{5}$ and $187.5 \mathrm{~kg} \mathrm{~K}_{2} \mathrm{O} \mathrm{ha}^{-1}$. At 20 days of corn planting, the plants were sprayed with a micronutrients solution containing $\mathrm{Fe}, \mathrm{Zn}, \mathrm{Mn}$ and $\mathrm{Cu}$. Irrigation was followed every fourth day with an amount of water to compensate loss in moisture which was maintained at field capacity. At 90 days of corn planting, plant height $(\mathrm{cm} /$ plant $)$ and water consumptive use by corn plants $(1 /$ pot $)$ were recorded. The above ground part of corn plants was cut. Then, fresh and dry weights of the corn shoots were recorded ( $\mathrm{g} / \mathrm{pot}$ ). Water use efficiency was calculated as gram production of dry matter/liter of the consumed water.

Laboratory analysis

\section{a. Soil and CKD chemical analysis}

1.pH was measured in a 1:2.5 soil-water (or CKD-water) suspension by a $\mathrm{pH}$ matter as described by Page et al. (1982).

2. Electrical conductivity was determined in a 1:5 soil-water (or CKD-water) extract using an EC meter as described by Page et al. (1982).

3.Total carbonates were determined using the calcimeter apparatus (Scheibler) as $\mathrm{CaCO}_{3}$ as described by Houba et al. (1974). 
4. Organic matter was determined as total carbon according to Walkley and Black's method (Page et al., 1982).

5. Soluble cations $\left(\mathrm{Ca}^{+2}, \mathrm{Mg}^{+2}, \mathrm{Na}^{+}\right.$and $\left.\mathrm{K}^{+}\right)$and soluble anions $\left(\mathrm{CO}_{3}{ }^{2-}, \mathrm{HCO}_{3}{ }^{-}\right.$, $\mathrm{Cl}^{-}$and $\left.\mathrm{SO}_{4}{ }^{2-}\right)$ were determined according to Page et al. (1982).

b. Soil physical analysis

1. Particle size distribution was carried out according to the international pipette method (Klute, 1986).

2. The percolation rate was determined and calculated according to Pankov (1974) from the following equation:

Depth of the percolated water $(\mathrm{cm})$

Percolation rate $=$

Time (min)

3. Infiltration rate was determined and calculated according to Singh (1980).

4. Particle and bulk densities were carried out according to Klute (1986).

5. Total porosity was calculated according to Klute (1986) from the following equation:

$$
\text { Porosity }(\%)=\left(1-\frac{\text { Bulk density }}{\text { Particle density }}\right) \times 100
$$

\section{Results and Discussion}

Comparison between the raw black CKD and white CKD

Data given in Table 2 show that the two CKDs had a high total soluble salts expressed as EC, soluble cations $\left(\mathrm{Ca}^{+2}, \mathrm{Mg}^{+2}, \mathrm{Na}^{+}\right.$and $\left.\mathrm{K}^{+}\right)$and soluble anions $\left(\mathrm{Cl}^{-}, \mathrm{SO}_{4}^{-2}\right.$ and $\left.\mathrm{CO}_{3}^{-2}\right)$.

Comparing the EC and soluble ions of each raw CKD, the results indicate that the values of $\mathrm{EC}, \mathrm{Cl}^{-}, \mathrm{Na}^{+}$and $\mathrm{K}^{+}$of the raw black CKD were higher than those of the raw white $\mathrm{CKD}$, however, the values of $\mathrm{Ca}^{+2}, \mathrm{Mg}^{+2}, \mathrm{CO}_{3}^{-2}$ and $\mathrm{SO}_{4}^{-2}$ of the raw white CKD were higher than those of the black CKD. These results are in a close agreement with those reported by Klemm (1980) who pointed out that the CKD vary markedly from plant to plant in chemical, mineralogical and physical composition, depending upon the feed raw materials, type of kiln operation, dust collection facility and the fuel used.

\section{Cement kiln dust modification}

It is known that the CKD has a high content of salts and soluble ions. Its application to a soil causes salinity build up in the soil. The CKD need to be leached so as to decrease its content of salts and soluble ions.

In the current study, each CKD was modified by leaching with water using four leaching treatments (leaching with 0, 5, 10 and 20 times water).

Egypt. J. Soil Sci. 53, No. 3 (2013) 
Data presented in Table 3 show the effect of leaching on some chemical properties of the two tested CKDs. As can be seen from Table 3, increasing the leaching treatrments from 0 times water (unleached) up to 20 times water gradually decreased the EC and soluble ions of both CKDs compared to those of the unleached ones.

The lowest values of $\mathrm{EC}, \mathrm{Ca}^{+2}, \mathrm{Mg}^{+2}, \mathrm{Na}^{+}, \mathrm{K}^{+}, \mathrm{Cl}^{-}, \mathrm{SO}_{4}^{-2}$ and $\mathrm{CO}_{3}{ }^{-2}$ were obtained when both CKDs were leached with 20 times water. Therefore, the best leaching treatment for the CKD is the leaching with 20 times water.

The values of $\mathrm{EC}, \mathrm{Ca}^{+2}, \mathrm{Mg}^{+2}, \mathrm{Na}^{+}, \mathrm{K}^{+}, \mathrm{SO}_{4}^{-2}$ and $\mathrm{CO}_{3}{ }^{-2}$ of the black $\mathrm{CKD}$, leached with 20 times water, relative to the unleached black CKD were 50, 32, $100,71,71,83,50$ and $14 \%$, respectively, while, those of the white CKD, relative to the unleached white CKD were $47,45,50,33,50,7,46$ and $40 \%$, respectively.

The values of the EC and soluble ions of the white CKD, leached with 20 times water, were lower than those of the black CKD, leached with the same amount of water. The exception was that the values of $\mathrm{Ca}^{+2}$, and $\mathrm{SO}_{4}{ }^{-2}$ of the white CKD, leached with 20 times water, were higher than those of the black CKD, leached with 20 times water. In other words, the leaching efficiency of the white CKD was better than that of the black CKD. Therefore, it was decided to use the modified white CKD in the pot experiment in order to study its effect on the sandy soil physical properties, corn growth, and water use efficiency by the corn plants.

Effect of the modified white CKD on some physical properties of the sandy soil

The modified CKD (leached with 20 times water) was applied to the sandy soil at six rates $\left(0,5,10,15,20\right.$, and $\left.25 \mathrm{Mg} \mathrm{ha}^{-1}\right)$. The effect of the modified white CKD on some physical properties of the sandy soil is illustrated in Table 4.

It can be observed from Table 4 that increasing the application rates of the modified white CKD from 0 (untreated control) up to $25 \mathrm{Mg} \mathrm{ha}^{-1}$ gradually decreased the particle density, total porosity, percolation rate, and infiltration rare of the sandy soil compared to those of the untreated one.

The lowest values of the above mentioned soil properties were obtained when the CKD was applied at the rate of $25 \mathrm{Mg} \mathrm{ha}^{-1}$. However, the bulk density was slightly decreased by increasing the application rate of the CKD. The values of bulk density, particle density, total porosity, percolation rate, and infiltration rate of the sandy soil were $96.8,92.1,93.2,66.9$, and $73.1 \%$; respectively; when the CKD was applied at the rate of $25 \mathrm{Mg} \mathrm{ha}^{-1}$ relative to the untreated soil.

The decrease in the values of these soil properties suggests that application of the modified white CKD to the sandy soil improves its hydro-physical properties and decreases the lost water by leaching. Moreover, such decrease was enhanced by increasing the application rate of the CKD. 
The decrease in the water movement (percolation rate and infiltration rate) of the sandy soil treated with the CKD may be attributed to the effect of the modified white CKD in increasing the amount of fine and colloidal particles in the treated soil, which partially blocked the macro pores and increased the soil micro pores, which in turn increased the hydraulic resistively of the treated sandy soils. Similar results were obtained by El-Sherif and El-Hady (1986) and Mekail (1988) who used the shales or bentonite in improving the sandy soil properties.

Effect of the modified white CKD on some corn vegetative growth parameters and water use by the corn plants

1. Some corn vegetative growth parameters

Application of the modified white CKD to the sandy soil generally increased the corn vegetative growth parameters (plant height and fresh and dry weights of the corn shoots) compared to those of the untreated soil as shown in Table 5. The increase in these growth parameters was proportional to the increase in the CKD application rate. The values of the plant height of the corn plants were 104.4, 109.2, 115.1, 117.5 and $119.5 \%$ for $5,10,15,20$ and $25 \mathrm{Mg}$ of CKD/ha, respectively, relative to that of the control treatment

TABLE 5. Effect of the modified white CKD on some corn vegetative growth parameters and water use by the corn plants.

\begin{tabular}{|c|c|c|c|c|c|}
\hline $\begin{array}{c}\text { CKD } \\
\text { treatments } \\
\left(\mathbf{M g ~ h a}^{-1}\right)\end{array}$ & $\begin{array}{c}\text { Plant } \\
\text { height } \\
(\mathbf{c m})\end{array}$ & $\begin{array}{c}\text { Fresh } \\
\text { weight } \\
\text { (g/pot) }\end{array}$ & $\begin{array}{c}\text { Dry } \\
\text { weight } \\
\text { (g/pot) }\end{array}$ & $\begin{array}{c}\text { Water } \\
\text { consumptive } \\
\text { use (1/pot) }\end{array}$ & $\begin{array}{c}\text { Water use } \\
\text { efficiency } \\
(\mathbf{g} / \mathbf{l})\end{array}$ \\
\hline Control (0.0) & 83.83 & 35.79 & 6.82 & 4.97 & 1.38 \\
\hline 5 & 87.50 & 39.59 & 7.17 & 4.84 & 1.48 \\
\hline 10 & 91.50 & 40.33 & 7.42 & 4.82 & 1.54 \\
\hline 15 & 96.50 & 47.11 & 8.70 & 4.79 & 1.82 \\
\hline 20 & 98.50 & 64.33 & 9.39 & 4.77 & 1.96 \\
\hline 25 & 100.20 & 67.19 & 10.77 & 4.71 & 2.29 \\
\hline
\end{tabular}

Relevant values for the fresh weight of the corn shoots were 110.6, 112.7, 131.6 and $187.7 \%$ and for the dry weight of the corn shoots were 105.1, 108.8, 127.6, 137.7 and $157.9 \%$ for 5, 10, 15, 20 and $25 \mathrm{Mg}$ of CKD/ha, respectively, relative to that of the control treatment.

The improvement in the studied growth parameters of corn may be due to the effect of the CKD on improving the hydro-physical and chemical properties of the treated soils. Consequently, the corn growth was enhanced. The obtained results and the prevailing discussion are in consistent with the findings of Lotfy and El-Hady (1984), El-Sherif and El-Hady (1986) and Mekail (1988) who used

Egypt. J. Soil Sci. 53, No. 3 (2013) 
the shales or bentonite in improving the sandy soil properties as well as Haynes and Kramer (1982), Naylor and Dangeau (1985), Dan et al. (1989), Fraiman et al. (1991) and Rahman et al. (2011) who used the CKD in improving the sandy soil properties.

2. Water consumptive use and water use efficiency by the corn plants

The water consumptive use by the corn plants was slightly decreased, while, the water use efficiency by the con plants was increased by increasing the application rate of the CKD (Table 5). The increase in the water use efficiency by the corn plants could be attributed to the increase in the dry weight of the corn shoots on one hand and the decrease in the water consumptive use on the other hand.

The increase in the water use efficiency by the corn plants ranged between 8.0 to $67.2 \%$ for 5 and $25 \mathrm{Mg} \mathrm{CKD/ha} \mathrm{relative} \mathrm{to} \mathrm{that} \mathrm{of} \mathrm{the} \mathrm{control} \mathrm{treatment.}$

The increase in the water use efficiency by the corn plants may be due that the CKD particles increased the soil water holding capacity and decreased the lost water by leaching, which increased the available water to the corn plants. Consequently, this available water will be used in producing much corn dry matter. These results are in harmony with those reported by Lotfy and El-Hady (1984), El-Hady and El-Sherif (1986) and Mekail (1988) who used the shales or bentonite in improving the sandy soil properties.

In general, application of the modified white CKD improves the sandy soil properties, decreases the lost water by leaching, rationalizes the irrigation water use and enhances the corn growth. Therefore, it could be recommended to use the modified white CKD at the rate of $25 \mathrm{Mg} \mathrm{ha}^{-1}$ as an amendment for the sandy soil under the conditions of El-Minia Governorate. Field studies are under application.

\section{References}

Adaska, W. S. and Taubert, D. H. (2008) Beneficial uses of cement kiln dust. Presented at 2008 IEEE/PCA $50^{\text {th }}$ Cement Industry Technical Conf., Miami, FL, 19-22, May 2008, pp. 1-19.

Carroll, D. M., Erickson, C. J. and Whittaker, C. W. (1964) Cement kiln flue dust as soil liming amendment. Journal of Agronomy 56: 373-376.

Dan, P. R., Dear, B. S. and Cunningham, R. B. (1989) Comparison of sewage ash, crushed limestone and cement kiln dust as ameliorants for acid soils. Australian Journal of Experimental Agriculture, Commonwealth Scientific and Industrial Research Organization, East Melbourne, Australia 29(4), (c.f. Adaska, W. S. and Taubert, D. H., 2008).

El-Awady, M. H. and Sami, T. M. (1997) Removal of heavy metals by cement kiln dust. Bulliten of Environmental Contamination and Toxicology 59: 603-610 
El-Hady, O. A. and El-Sherif, A. F. (1986) Greenhouse observations with sand-bentonite mixtures on germination, growth, water use efficiency, and nutrients uptake. Egyptian J. of Soil Sci., Special Issue.

El-Sherif, A. F. and El-Hady, O. A. (1986) The possibility of using Egyptian bentonite deposits for sandy soil reclamation and planting. Egypt. J. of Soil Sci., Special Issue, 171-180.

Fraiman, L. S., Loganson, A. K. and Solovashkov, N. E. (1991) Study of properties of bypass dust. Tsement, Leningrad, USSR, Vol. 9-12 (c.f. Adaska, W. S. and Taubert, D. H., 2008).

Haynes, W. B. and Kramer, G. W. (1982) Characterization of U.S. Cement Kiln Dust. Information Circular \#8885, U.S. Bureau of Mines, U.S. Department of Interior, Washington, D. C. ( c.f. Rahman, M. K., Rehman, S., and Al-Amoudi, O. S. B., 2011).

Houba, V. J. G., van Schouwenburg, J. Ch. and Walinga, I. (1974) Methods of analysis for soils. II. Soil analysis, 1974, Wageningen, The Netherlands.

Khader, S. and Abu-Rub, N. (1986) The potential use of cement dust as a fertilizer. Dirasat., Vol. 13. No. 5. pp, 51-60 (c.f. Rahman, M. K., Rehman, S. and Al-Amoudi, O. S. B., 2011)

Klemm, W. A. (1980) Kiln dust utilization. Martin Marietta Laboratories Report MML TR 80-12, Baltimore, Maryland, U.S.A.

Klute, A. A.(1986) "Methods of Soil Analysis, Part 1: Physical and Mineralogical Methods", $2^{\text {nd }}$ ed., Am. Soc. Agron. Inc. Publisher, Madison, Wisconsin, USA.

Lotfy, A. A. and El-Hady, O. A. (1984) Effect of bentonite on some characteristics, yield, and water use efficiency of kidney bean in sandy soil under trickle irrigation. Egypt. $J$. Soil Sci. 24 (3): 225-235.

Mekail, M. M. (1988) Evaluation of shale deposits of El-Minia Governorate as a soil conditioner. M. Sc. Thesis, Faculty of Agric., El-Minia University, El-Minia, Egypt.

Naylor, L. M. and Dagneau, J. C. (1985) Cement kiln dust: A resource too valuable to waste. Toxic Hazardous Wastes, Proc. $17^{\text {th }}$ Mid-Atlantic Industrial waste Conference, pp. 353-366

Page, A. L., Miller, R. H., and Keeney, D. R. (1982) "Methods of Soil Analysis, Part 2. Chemical and Biological Properties". Agronomy 9, $2^{\text {nd }}$ ed., Am. Soc. Agron., Madison, Wisconsin, USA.

Pankov, M. A. (1974) Land reclamation. TUUMCX publisher, Tashkent, USSR.

Rahman, M. K., Rehman, S. and Al-Amoudi, O. S. B. (2011) Literature review on cement kiln dust usage in soil and waste stabilization and experimental investigation. IJRRAS, 7, Issue 1, April 2011: 77-87. 
Rodd, A. V., McRae, K. B., Macleod, J. A., Warman, P. R. and Grimmett, M. G. (2009) Surface application of cement kiln dust and lime to forage land: Effect on forage yield, tissue concentration and accumulation of nutrients. Canadian Journal of Soil Science 201-213.

Schreiber, R.J., Smeenk, S. D. and Shreiber, Y. (1998) Acceptable approaches for beneficial use of cement kiln dust. Waste combustion in boilers and industrial furnaces specialty conference, Air and Waste Management Association, Pittsburgh, PA, USA, 15-17 Apr, pp. 105-118

Sing, R. A. (1980) "Soil Physical Analysis", Kalyani Publishers, New Delhi-Ludniana.

Waly, T. A., Dakroury, A. M., Sayed, G. E. and El-Salam. S. A. (2007) Assessment removal of heavy metals ions from waste-water by cement kiln dust (CKD). Eleventh International Water Technology Conference, IWTC11 2007, Sharm El-Sheikh, Egypt, pp: 879-893.

(Received 14/11/2012; accepted 18/ 5/ 2014) 


\title{
تقييم تراب فرن الأسمنت كمحسن للأراضي الرملية 10 - دراسات مبلئية \\ محمود أحمد مرسي ، جمال مصطفى الضوي ، حسن علي حسن و كوثر هارون محمد

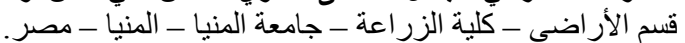

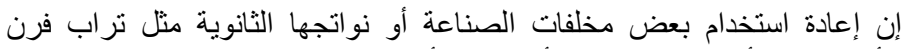

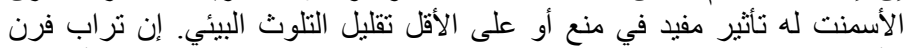

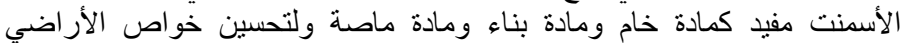

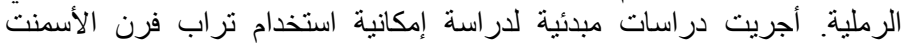

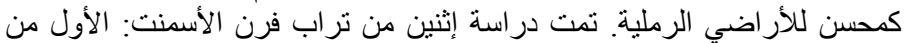

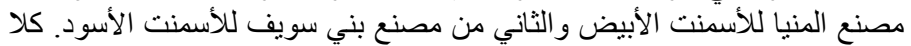

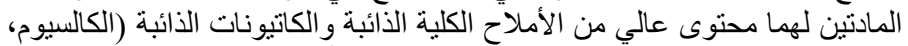

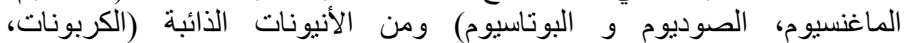

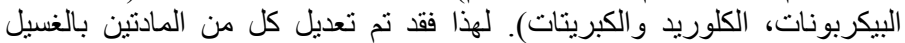

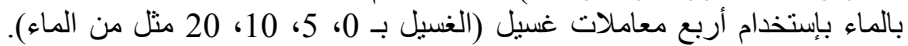

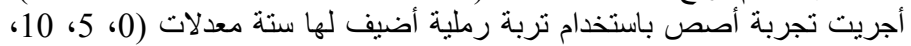

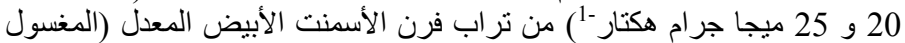
بـ 20 مثل من الماء) لدر اسة تأثثيره كمحسن تربة.
\end{abstract}

توضح نتائج الدراسة أن تراب فرن الأسمنت الأسود يحتوي على أملاح ذائبة

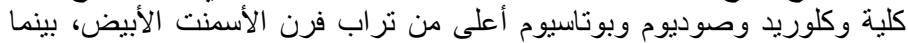

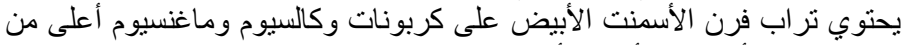

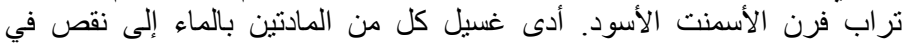

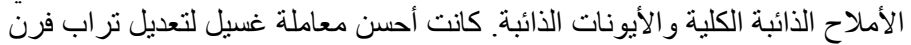

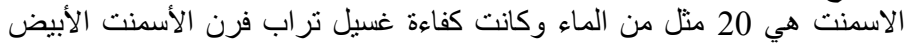

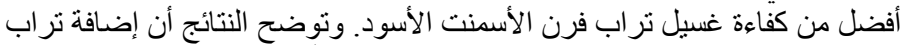

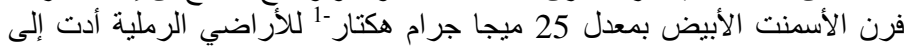

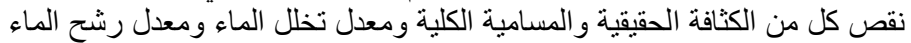

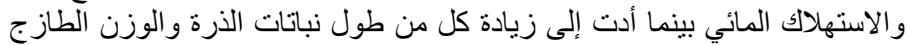

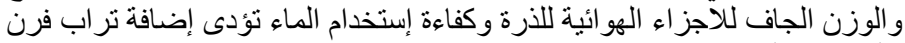

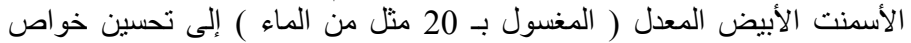

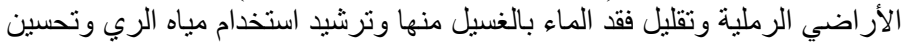

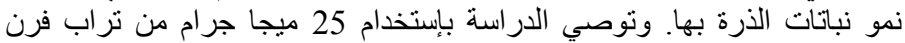

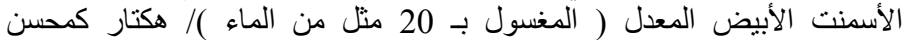
للأر اضي الرملية تحت ظروف محافظة الإنيا. 